\title{
Regional issues on road accidents and traffic injury in Ukraine
}

\author{
Anatolii Kornus**a , Olesia Kornus ${ }^{\mathrm{a}}$, Volodymyr Shyschuk ${ }^{\mathrm{b}}$
}

a Sumy State Pedagogical University, Ukraine

b Sumy State University, Ukraine

This paper aims to analyse death and injury frequencies caused by road accidents in different regions of Ukraine. Types of road accidents and their degree of severity are analyzed, in addition to the level of road accidents in Ukraine compared to the same parameters in Europe. 2007 and 2013 death rates and injury rates due to car crashes or traffic accidents are considered as ratio per 1,000 inhabitants and 1,000 cars. An overall geographically featured assessment of road injuries has also been computed for each administrative region of the country. An evaluation of an integrated road safety index based on the statistical analysis of road accidents indicators has been developed (primarily making use of factor analysis such as principal component analysis and correlation analysis). Assessment of an integrated road safety index has been introduced since this enabled us to differentiate and identify a variety of regional categories related to traumatism and mortality rates due to road accidents.

Key Words: road traffic accidents, injury, mortality, culprits, road safety index, Ukraine.

Article Info: Received: July 30, 2016; Final revision: November 5, 2017; Accepted: November 16, 2017; Online: November 25, 2017.

\section{Introduction}

Ukrainian demography has experienced and continues to face serious mortality dynamics, most aspects being problematic. According to some specialists Ukrainian population goes through a mortality crisis determined by a long-term negative trend during 1965-1984. This trend grew and intensified by the consequences of the Chernobyl disaster in 1986 and the negative impact of the

\section{* Corresponding author}

Address: Department of General and Regional Geography, Sumy State Pedagogical University, 87 Romens'ka street, Sumy 40002, Ukraine.

Phone: + 38 (0542)33-10-81 | Email: a_kornus@ukr.net

(C)2017 Human Geographies; The authors

(c) (i) This work is licensed under a

Creative Commons Attribution 4.0 International License. DOI:10.5719/hgeo.2017.112.5 


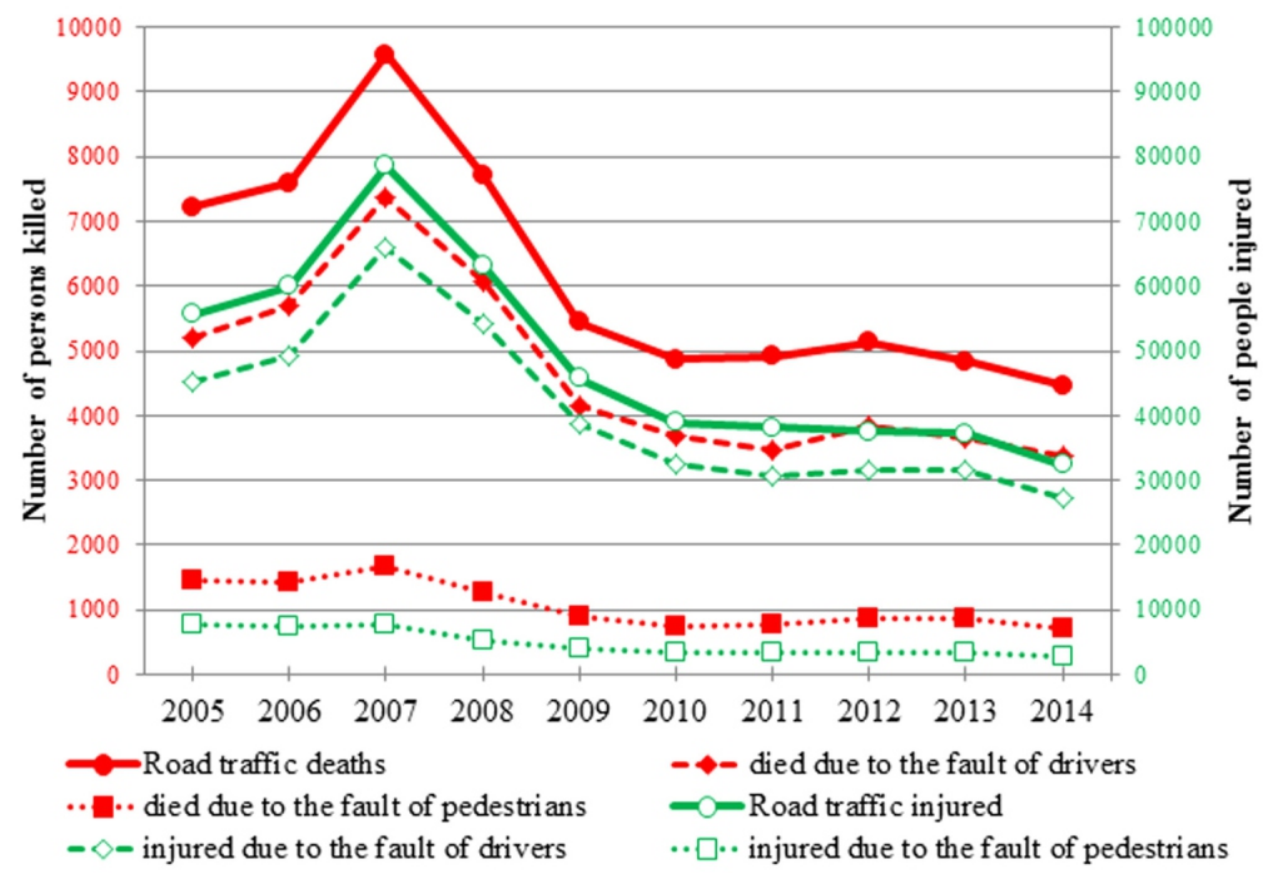

Figure 1. Lost lives/deaths (left axis) and casualties/injuries (right axis) in road accidents Source: statistics of road accidents in Ukraine.

protracted economic crisis during 1991-1998. Unfortunately, the mortality rate in Ukraine over the past ten years remains one of the worst ones as compared to mid-1990s, when the maximum of the population mortality occurred. The extended stagnation of high mortality rate caused the depopulation in Ukraine. During the past ten years (2005-2015), the overall mortality rate in Ukraine has been kept at a quite high a level compared to the European countries 14.716.6\%o (Kovalchuk, 2014; Kvitashvili, 2015).

The current structure of causes of death of the population of Ukraine combines elements of traditional and modern structures of pathologies, in which the high mortality rate from endogenous diseases (cardiovascular diseases and neoplasms) is coupled with equally significant mortality from diseases of respiratory apparatus, digestive system, infectious, parasitic diseases and external (exogenous) reasons, first of all, as injuries (Kvitashvili, 2015). Road traffic accidents have a special place among the external factors causing injuries and increasing morbidity and mortality. Since the 2010s, about 4,500-5,000 people die each year due to road accidents in Ukraine, which is about $1 \%$ of all deaths in the country and about $15 \%$ of all deaths caused by external factors (Kvitashvili, 2015; Statistical yearbook, 2015). Each year another 45,000-50,000 people are injured because of car crashes/road accidents (Statistics of road accidents, 2016) (Figure 1).

Accidents on the roads and their consequences are the subject of attention for physicians, economists, sociologists, road construction experts, logistics, etc. (Lyebyedyeva, 2015; Myronenko, 2013). Not so many scientific papers are dedicated to geographical aspects of road traffic accidents in Ukraine. They deal with the quantitative characteristics of the accidents at the Ukrainian roads and their dependence on the level of socio-economic development of regions 
(Avramenko, 2015). In another study (Statystyka, 2014) is compared mortality rate in road accidents in Ukraine and other countries of the world. Geographical analysis of traffic accidents in some regions of Ukraine, including geography and dynamics of accidents, is presented by Shischuk et al. (2016).

The main goals of the present article are: to reveal the major indicators of traffic crashes-leading to increased danger on roads and to characterise the main types of road accidents and their influence on mortality and traumatism rates. We also aim to estimate the level of road safety for all regions of Ukraine by determining the road safety index (RSI).

\section{Methodology}

A complex methodology was applied to determine the level of road accidents in different regions of Ukraine. It consists of several stages, such as:

1) selection of indicators reflecting the number and severity of accidents on the Ukrainian roads and streets and the number of culprits/accident, as well as causes for the occurrence of traffic crashes;

2) bringing diverse indicators to a single standardised range by the feature scaling;

3) calculation of the integrated road safety index.

Many data sources allow you to compare road safety in the EU, Ukraine and other countries around the world. Back in 2004, the World Health Organization (WHO) and the World Bank published the World report on road traffic injury prevention (Peden, 2014). It contained extensive information on the key risk factors for road traffic injuries, information about effective measures and recommendations on how countries can improve a road safety. In 2009, the first data on the implementation of these recommendations were published in the Global status report on road safety: time for action.

In 2010, the UN General Assembly unanimously adopted the resolution 64/255 (Improving, 2010), and called for to undertake in the 2011-2020 the Decade of Action for Road Safety. To track the results of the Decade on national and global levels, it was proposed to prepare follow-up reports on road safety. The Decade of Action for Road Safety (2011-2020) (Global plan, 2011) calls on countries to implement the measures identified internationally to make their roads safer. The UN General Assembly invited WHO to monitor progress through its Global status report on road safety series. At the end of 2013, the Global status report on road safety 2013: supporting a decade of action was published.

During 2013-2015 worldwide the total number of road traffic deaths has plateaued at 1.25 million per year, with the highest road traffic fatality rates in low-income countries. But, while there has been progress towards improving road safety legislation and in making vehicles safer, the report shows that the paces of change are too slow. Urgent action is needed to achieve the ambitious target for road safety reflected in the newly adopted 2030 Agenda for Sustainable Development: halving the global number of deaths and injuries from road traffic accidents by 2020 . 
The next Global status report on road safety 2015 contained information obtained from 180 countries (Global status, 2015). Three types of traffic accident mortality data are presented in the report: (i) the data reported by the national focal points; (ii) the corrected data; (iii) the comparable estimates. Data reported by national experts are presented in the report in the appropriate "country profiles'. It also identifies data sources, the period to which they relate, as well as the time frame used in the accounting of deaths from road accidents. To minimise the impact of differences in the definition of death from accidents and harmonise data from different sources, they were corrected by 30-day definition for their official road traffic fatality data. The comparable estimates (and their corresponding 95\% confidence intervals) were developed to compensate data underreporting in some countries and to assess mortality from accidents in all WHO member countries of 2013. Unfortunately, Ukraine was not included in this global WHO report.

Besides that, The United Nations Economic Commission for Europe (ECE) publishes the Bulletin on statistics of road traffic accidents in Europe and North America. In 2015 the fifty-third edition of the Statistics of Road Traffic Accidents in Europe and North America (Statistics, 2015) was published; it contains basic statistics on road traffic accidents provided by the Governments of 56 member countries of the United Nations Economic Commission for Europe (UNECE). The statistics in this document is limited to road traffic accidents involving personal injury, and excluding accidents where only damage to vehicles is reported.

The Statistics for Road Traffic Accidents in Europe and North America is divided into three basic parts. The first part sets out charts and summary tables on the overall situation and developments in road traffic accidents and casualties in UNECE countries. The second part provides detailed statistics on road traffic accidents and includes the details of accidents such as location, time of occurrence, road condition, personal injuries and deaths. The third part shows background statistics on countries' vehicle fleets and estimates of the vehiclekilometres run.

In Ukraine, the statistics of accidents, deaths and injuries in the road accident is provided by the Ukrainian medical council for road traffic of Ministry of Health and the Office for Road Safety of the National Police of Ukraine. The Ministry keeps statistics of traffic accidents by WHO methodology (International, 2015), so its representation is much better and more objectively reflects the situation on the roads of Ukraine. However, these data are not published nowhere. Thus, the data from the Office of Road Safety are only available.

To study the features and trends of road accidents on the roads of Ukraine we used various indicators characterizing its two main aspects of this problem: a) the number and severity level of accidents (the total number of deaths and injuries resulting of road and street traffic crashes; the total number of all accidents per number of accidents with victims; percentage of accidents with victims of the total number of traffic accidents; the number of fatal and non-fatal accidents with victims that have occurred within settlements, and the percentage of these accidents of all traffic accidents with victims. Based on the analysis of these indicators, the death and injuries rate per 1,000 cars/people was calculated for each administrative region separately, and b) the structure of the road traffic 
accidents (in particular, the structure by types of crashes (collisions with another vehicle, include head-on and rear-end collision, angle or side impacts; rollover crashes, collision with stationary vehicles; collision with stationary obstruction, such as a tree, utility pole or road debris; collisions involving pedestrians and cyclists; collisions with animals and cartage transport; passengers fall (from a moving vehicle or inside it due to hard braking, accelerating or changes in direction of movement) and cargo carried fall or fall of subject, rejected by wheel on human, animal or another vehicle was investigated); the number and percentage of accidents that have occurred due to drivers (including drunk drivers) or due to pedestrians (including children) were calculated separately.

All necessary data for calculations we have received from the Office of Road Safety of the Department of preventive activity of the National Police of Ukraine (Statistics of road accidents, 2016).

Normalized data were calculated for each region. The equation for normalizing is the following:

$$
X^{\prime}=1-\frac{x_{i}-x_{\min }}{x_{\max }-x_{\min }}(1)
$$

where $\mathrm{X}^{\prime}$ - the data point i normalized between 0 and 1 ; $\mathrm{x}_{\mathrm{i}}$ - each data point; $\mathrm{x}_{\min }$ - the minimum value; $x_{\max }$ - the maximum value.

Scaling (unity-based normalisation) was used for bringing all values into the range $[0,1]$. Therefore, all parameters should have the same scale for the appropriate comparison. The value 0 and 1 are characteristic of regions with, respectively, the smallest or the largest value of a given indicator among the administrative regions of Ukraine.

As has been stated above, the first step in the calculating of RCI was a selection of indicators of road traffic accidents and the severity of accidents. Such indicators were: a total number of road accidents; traffic accidents in settlements; road traffic deaths; road traffic injuries; rollover crashes; collisions with stationary vehicles; collisions with stationary obstruction; collisions involving pedestrians; collisions involving cyclists; another types of road crashes; road accidents due to drivers; persons killed due to drivers; persons injured due to drivers; road accidents due to drunk drivers; persons killed due to drunk drivers; persons injured due to drunk drivers; road accidents due to pedestrians; persons killed due to pedestrians; persons injured due to pedestrians; road accidents due to children-pedestrians; persons killed due to childrenpedestrians; persons injured due to children-pedestrians in 2007 and in 2013.

The second step was bringing of diverse indicators characterising the frequency of different types of road crashes, traumatism and mortality in traffic accidents to a single standardised range by feature scaling by the procedure mentioned above. The sum of the standardised values of these indicators characterising the frequency, traumatism, and mortality in traffic accidents is an integrated RSI. This index is the coefficient, which characterises the level of the road safety in the separate administrative region.

All calculations and statistical computations (factor analysis, in particular, principal component analysis and correlation analysis) and test the statistics, as well as the graphical representations were obtained by using the capabilities of 
the computer package IBM SPSS Statistic 23.0 from IBM Corp., Microsoft Excel 2010 of Microsoft Corporation and Statistica 10 from the StatSoft Inc.

\section{Main determinants affecting road safety}

The high level of road traffic accidents in Ukraine is highly dependent by three groups of factors, known as 'epidemiologic triad' (Haddon, 1972): human factors, vehicles and equipment factors, and environmental factors.

Human-related factor. First of all the high level of road traffic accidents in Ukraine is highly dependent by the human factor: behaviour of drivers, their unpreparedness, foolhardiness on the road, drunk driving, drunk pedestrians, and, finally, violation of road rules by drivers and pedestrians. The main responsibility for the accident and its consequences lies with the drivers. According to statistics for 2013, about 25,600 of the nearly 30,700 road accidents with victims $(83.6 \%)$ were due to drivers fault. If we take these estimates, it is clear that the main attention should be paid to the behaviour of the person behind the wheel. Speeding is the main contributing factor in fatal crashes. Both excess speed (exceeding the posted speed limit) and inappropriate speed (faster than the prevailing conditions allow) are important causation factor of road accidents. These are the most frequent violations by Ukrainian drivers involved in an accident. As in European countries (Road Safety, 2014), speeding in Ukraine is the cause of about $30 \%$ of fatal accidents, e.g. the share of fatal crashes in Ukraine due to excessive speed was 31.3\% in 2013 (Statistics of road accidents, 2016).

However, speeding is only one of the traffic violations, although it is the most fatal. About $20.2 \%$ of all road traffic accidents with victims in Ukraine were attributed to a violation of the rules of manoeuvring, and $7.2 \%$ - crossing of intersections as the main causes for the crash (Statistics of road accidents, 2016). Drunk driving is the third major cause of car crashes and casualties in Ukraine. In 2013, 6.6\% of fatalities were due to drunk driving. Drunk drivers ignore the traffic rules very often and usually fall on their feet in any case.

Another problem of road safety in Ukraine is the attitude to passive safety. The proportion of seat-belt use is $27 \%$ for drivers and $25 \%$ for front seat passengers (in passenger cars). At the same time, about $10 \%$ of Ukrainian drivers believe the seat belts are useless, so these people fasten their seatbelts in extreme cases only. Moreover, almost $10 \%$ of drivers believe that use of seat belts is pointless or even dangerous.

Vehicle-related factor. In 2013, the road vehicle fleet of Ukraine totalled 6.9 million of passenger cars, about 1.3 million lorries and road tractors, as well as 253 thousands of buses (Statistics, 2015). Vehicle fleet of Ukraine is quite old. Almost $27 \%$ of it is older than 25 years. Let us add to it 2.8 million vehicle age from 10 to 15 years. It turns out that 6 of 10 vehicles are over 10 years. The average age of passenger car fleet is 19.6 years (average age in EU-28 countries is 9.7 years) (The automobile, 2015).

Motorization rate for a long time considered as one of the most important factors, determining the number of road accidents and the severity of their effects. Over the past decades, the level of motorisation of the population of the 
EU-28 has increased significantly - from 334 cars per 1,000 resident population in 1991 to 473 in 2009 and 564 in 2013. The value of motorisation rate among the countries of EU-28 varied in 1991 from 63 per 1,000 people in Romania to 522 in Luxembourg, and in 2013 - from 253 to 769 cars per 1,000 people in these countries (Motorisation rate, 2015; The automobile, 2015). During 20052007, the growing level of motorization rate in Ukraine (from 111 to 121 cars per 1,000 Inhabitants) was accompanied by an increase of a road accident mortality rate (from 1.37 to 1.7 deaths per 1,000 cars) as well as injury rate (from 10.57 to 13.94 victims per 1,000 cars). However, in subsequent years, the motorisation rate in Ukraine was continued to grow, and reaching 204 cars per 1,000 inhabitants in 2013, while the injury rate and death rate declined and stabilised at the level of 5.8 and 0.8 victims per 1,000 cars, respectively.

Despite the big number of old cars, the percentage of traffic accidents where the emergency state of the vehicle was the main reason is usually small. In Ukraine, the total number of persons killed in road accidents due to vehicle malfunctions in 2013 was of only 61 (1.2\%). The main causes of such accidents in Ukraine are the failure of the brake system and excessive tire wear (Statistics of road accidents, 2016). In addition to the drivers, pedestrians acting as violators of traffic rules contribute to the deterioration of the situation on roads. Pedestrian culture in Ukraine is rather poor. People often cross the streets, ignoring pedestrian crosses and red lights. According to the Traffic Police, for 2013 because of violations of traffic rules by pedestrians 4.4 thousands of accidents were registered (14.4\% of all traffic accidents with victims), which killed 1,000 and injured about 4,000 people. The most common type of violation is the transition of the carriageway at an undisclosed location or an unexpected exit of pedestrians to the roadway. These two kinds of violations accounted $81.2 \%$ of the total number of road accidents committed by pedestrians (Statistics of road accidents, 2016).

Environment-related factor. The total length of public paved road in Ukraine is 166.1 thousand $\mathrm{km}$ (Statistical yearbook, 2015). The road network in Ukraine is characterised by low density $-0.28 \mathrm{~km}$ road $/ \mathrm{km}^{2}$ land area. At the same time, in neighbouring Slovakia, the road density is 0.88 , and in Romania $-0.47 \mathrm{~km}$ $\mathrm{road} / \mathrm{km}^{2}$ (Road Statistics Yearbook, 2016). A small length and the density of the road network cause a big number of vehicles per $\mathrm{km}$ of road in comparison with other European countries. Today in Ukraine are over 50 vehicles per $\mathrm{km}$ of road, while in Slovakia - 47.6, and in Romania - 45.5 vehicles per $\mathrm{km}$ of road. Usually, every day the Ukrainian Traffic Police registered about 500 violations of road rules. But it has a strong reputation for fishing for bribes, so the control of road safety in Ukraine is very weak, resulting in a weak driving culture.

The acceleration of motorisation has not yet led to a corresponding increase in the volume of construction and reconstruction of the road network. From 2001 to 2013, the Ukrainian car fleet increased by 2 times, but the length of paved roads increased by only $1.3 \%$ (Transport and Communications of Ukraine, 2014). One of the main problems of the Ukrainian road network is its low quality. Only about $40 \%$ of Ukrainian paved roads comply with the regulatory requirements for transport and operational indicators of strength, $37 \%$ have an unsatisfactory evenness of pavement. Overall, about $60 \%$ of the public paved roads do not meet the regulatory requirements. On the motorways, there 
are many single-level three-way intersections, and four-way crossroads, inadequate security of barrier fences, bad lighting and road markings, about $20 \%$ of bridges are in poor condition (Transport and Communications, 2014). There are no sidewalks; roadsides are in bad condition due to the dangerous location of trees and poles.

Ambulance in Ukraine provides almost complete coverage of accidents in urban areas, but it is fewer when it comes to long-distance roads, where about $30-35 \%$ of all road accidents occur. In urban areas, emergency medical services provide help quickly enough, but on the roads, it takes time for the arrival of the medical team. There is a 30-minute standard, which the ambulance tries to maintain, although this is not always possible. In Ukraine the system of organisation of emergency team arrival to the scene of an accident and assistance to the victims is ineffective. Almost $70 \%$ of the cases of deaths which occur are directly linked with the transportation of victims to hospitals. Often the victims are transported from the accident site by a passer-by. When transported by passers-by killed more than $80 \%$ of the victims. Only $20 \%$ of deaths before arrival at the hospital were associated with injuries incompatible with life, and $80 \%$ due to inadequate medical care at the accident scene and during transport to the hospital (Shyschuk, 2011).

Hospitals provided their specialised care differently, and not all of them have a staff of traumatologists and equipment for treatment of victims with multiple and severe injuries. Treatment of patients can be performed by surgeons without sufficient and modern training in the field of traumatology. Also, not all hospitals that receive the victims of road accidents are staffed by a trauma surgeon. This leads to next transporting of victims, which increases the time to provide a qualified medical care. It is interesting that $70 \%$ of drivers do not know the purpose of medical preparations, which are in the first-aid kit. The shelf life of medicines, stored therein, is not controlled (Shyschuk, 2011).

\section{Road accidents in Ukraine and Europe - a geographical approach}

Each year in Europe, road traffic accidents killed over 90000 people, and about 26000 people died on the roads of the European Union (Road fatalities, 2016). Road traffic injuries in the WHO European Region result in an annual loss of 3.6 million years of healthy life due to premature death or disability (disabilityadjusted life-years). The loss of national productivity is an economic threat, resulting in high social costs equivalent $0.36-3.90 \%$ of the gross domestic product (Beckmann, 2007; Borovkov, 2011). Annual losses of Ukraine due to accidents are USD 4-5 billion (Koskovetskyi, 2015).

A large number of the non-fatal injuries (taking into account the cost of medical care, social security payments, production losses, etc.) for the country is more expensive than fatal accidents. For the WHO European Region, this translates into hundreds of billions of euros, including health service costs to treat and rehabilitate injured peoples (Global status, 2015; Jackisch, 2015).

For every death on European roads, there are any four permanently disabling injuries such as damage to the brain or spinal cord, eight serious injuries and fifty minor injuries. In 2013 death rate in road traffic accidents in the 
European Union was 5.9 per 100,000 inhabitants, that is below the world average, which is 18.8 per 100,000 inhabitants (Causes of death, 2013; Road traffic deaths, 2016).

However, there are significant differences in mortality in road accidents in different European countries. In low- and middle-income countries, this figure shows a twice as high index of high-income countries. For example, Sweden, Denmark, the United Kingdom are characterized by one of the world's lowest mortality rates in road accidents (about 3-4 deaths per 100,000 inhabitants). Among the EU countries, the highest rates of road traffic deaths in 2013 are in Lithuania and Poland - 10.6 and 10.3 per 100,000 inhabitants, respectively (Road traffic deaths, 2016).

Compared with this, the average death rate in road accidents in the CIS countries is almost four times higher. The highest rate among them is in Kazakhstan (24.2 deaths per 100,000 inhabitants), next followed by Kyrgyzstan (22.0 per 100,000 people) and the Russian Federation (18.9 per 100,000 inhabitants). Many Western European countries tended to decrease the number of car crashes and mortality in traffic accidents (Road traffic deaths, 2016). At the same time, in the eastern part of Europe, the reverse trend is observed death rates in the road accidents remain constant or growing there. For example, in Ukraine, the death toll on the roads and streets during 2010-2014 amounted to 4,400-5,100 people annually. The rate of road accidents for the year 2013 was 0.68 accidents with victims per 1,000 inhabitants. In 2013, about 170 people perished per 1000 road accidents with victims. The injury rate in the accidents on the roads in 2014 was 1,241 per 1,000 registered traffic accidents with victims in Ukraine (Statistics of road accidents, 2016).

Pedestrians are the main category of people who killed in road accidents. In 2013, 1,888 pedestrians (39.1\% of all road traffic deaths) were killed in the traffic accidents (Statistical yearbook, 2015). Approximately the same portion is drivers and passengers of cars, who killed in traffic accidents $-1,874$ people (38.8\%). About $70 \%$ of all perished drivers and car occupants have not used the seat belts (Statistics of road accidents, 2016). As can be seen, these two categories account for about $80 \%$ of all deaths on the Ukrainian roads. In 2007, the percentages of the types mentioned above of road users were lower: pedestrians $-37.5 \%$, drivers and car occupants - 29.9\% (Statistical yearbook, 2015).

That is why we focus on the geographical features of road injuries, including the fatal accidents, in different regions of Ukraine. Also, we drew attention to the two main groups of culprits of such accidents: drivers and pedestrians, who are both the main victims of the road accidents.

The highest rate of accidents with victims in 2007 was observed in the city of Sevastopol' and the Kyiv region (more than 2 traffic accidents per 1,000 inhabitants. High, relative to the average in Ukraine, was the level of road accidents in Donets'k, Odesa, Chernivtsi, Zaporizhzhya, and Dnipropetrovs'k regions (1.5-2 accidents per 1000 inhabitants). The smallest amount of the road accidents per 1,000 people was registered in the Ivano-Frankivs'k (0.86), Ternopil' (0.77) and Chernihiv regions (0.64 accidents per 1,000 inhabitants). In 2013, the most of all road traffic injuries remain in Sevastopol' and Odessa region (1-1.25 accidents per 1,000 people); slightly best situation was recorded in the Chernihiv, Ivano-Frankivs'k and Ternopil' regions - 0.28-0.30 accidents 


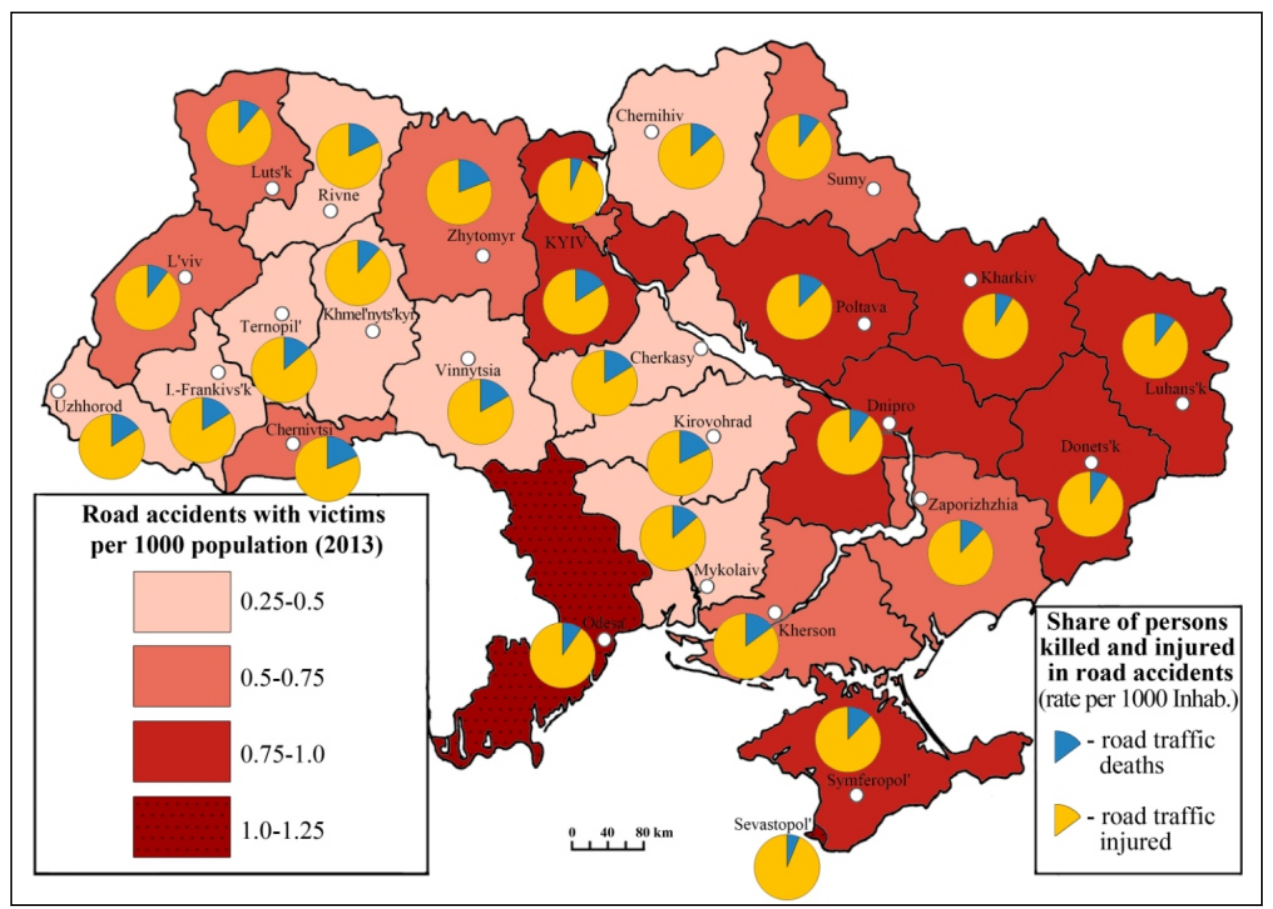

Figure 2. Standardized rate of traffic accidents per 1,000 Inhabitants

Source: statistics of road accidents in Ukraine.

with victims per 1,000 inhabitants (Figure 2).

However, the number of accidents is not always consistent with their severity. In particular, most of all fatal accidents during 2007 were observed in Kyiv (0.45 road deaths per 1,000 inhabitants), Zhytomyr (0.27), Chernivtsi (0.27), Poltava regions and in the Autonomous Republic of Crimea (at 0.26 killed in road accidents per 1,000 population). In 2013, fatal accidents were also more often in Kyiv, Chernivtsi and Zhytomyr regions, although the death rate due to the transport accidents has been decreased to $0.15-0.23$ per 1,000 inhabitants.

Given the different level of motorisation in the regions of Ukraine, the highest rate of the road accidents in 2007 was observed in the city of Sevastopol' (18 road accidents with victims per 1,000 cars), as well as Odessa and Donets'k regions (17.0-17.6 road accidents per 1000 cars). Best situation was in the city of Kyiv (6.8), and in the Chernihiv and Transcarpathian regions (7.7-7.8 road accidents with victims per 1,000 cars). The majority of the fatal accidents happened in Chernivtsi and Kyiv regions - 2.7-2.8 road deaths for 1,000 cars and the best situation was in Kyiv ( 0.75 fatalities per 1,000 vehicles).

In 2013, despite the increase of motorisation in all regions of Ukraine, the level of the road traffic injuries had significantly declined. This again suggests that the motorisation rate today is not the index determining the level of road traffic injuries. The number of road accidents in the city of Sevastopol' decreased from 18.0 to 10.3 and, for example, in the Donets'k region - from 17.6 to 7.4 road accidents with victims per 1,000 cars. The best situation was in the Ternopil', Vinnytsia, Mykolayiv and Kirovohrad regions, where 2.4-2.5 road accidents with victims per 1,000 cars were recorded in 2013 (Figure 3). 


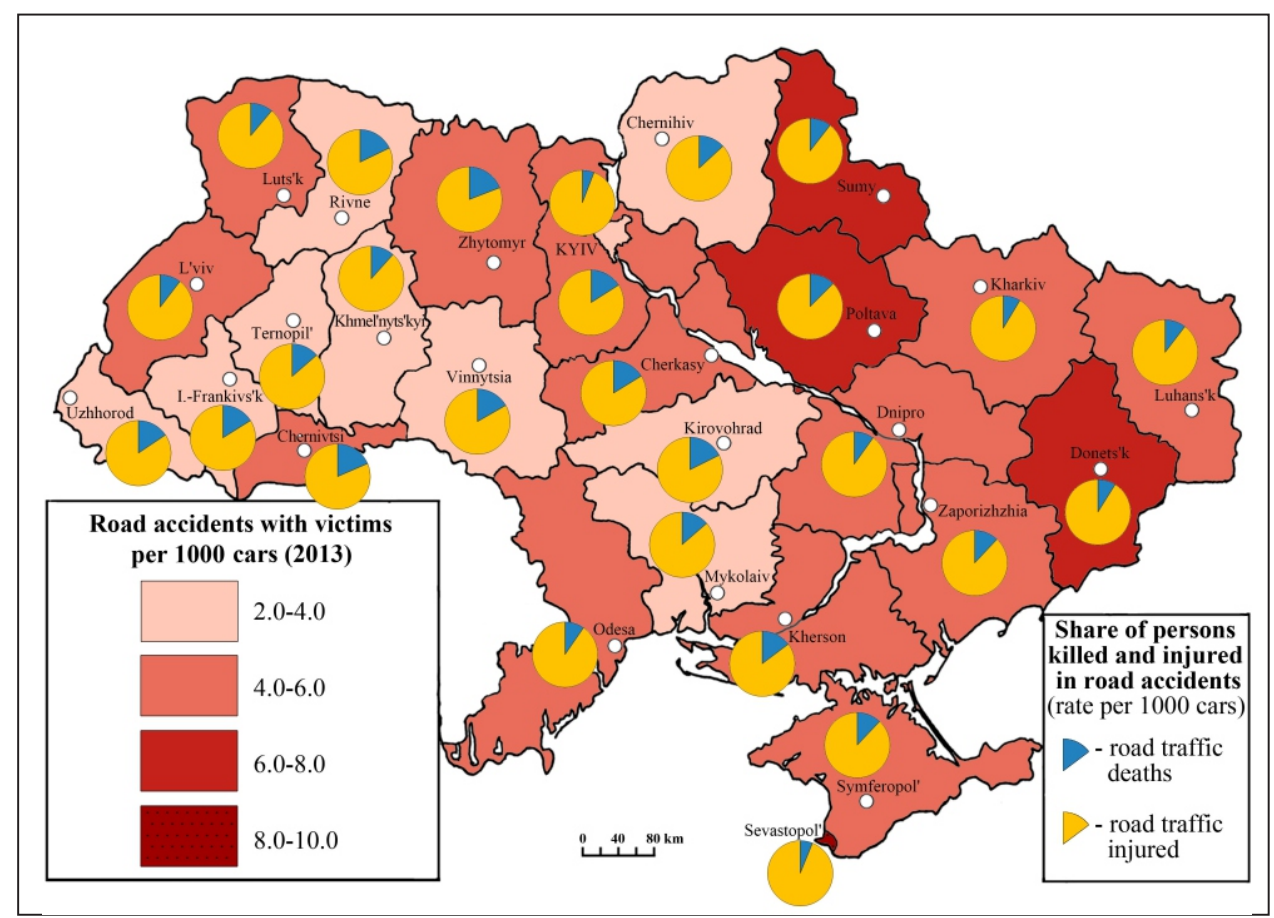

Figure 3. Standardized rate of traffic accidents per 1,000 cars Source: statistics of road accidents in Ukraine.

As in previous cases, the number of accidents is not consistent with their severity. In particular, most of all fatal accidents during 2013 were observed in Chernivtsi (1.16), Poltava and Zhytomyr, regions (1.27 road fatalities per 1,000 cars). Such a discrepancy between the number of road accidents and the number of deaths may indicate deficiencies of health care for persons affected by road accidents in different regions of Ukraine.

\section{Road safety index by Ukrainian regions}

For the overall assessment of the geographical features of road injuries, we have been computed the value of RSI for 2007 and 2013, calculated by the method described above for each of the administrative regions of Ukraine. In amount 2007, the largest number of best indicators (12 of 23) of the low level of the road accidents and traffic injuries are in two regions - the cities of Kyiv and Sevastopol'. Kyiv is characterised by the smallest standardised values of the road accidents with victims of the total number of all accidents, as well as crashes with rollovers, collisions involving pedestrians and cyclists in the structure of accident with victims. Also in Kyiv, there are the smallest amount of accidents due to drunk drivers and the lowest standardised values of accidents that have occurred due to of children-pedestrians, as well as the number of children, injured in such accidents.

Sevastopol' is characterised by the smallest standardised value of mortality rate in the road accidents (only 0.08 perished per one accident), the least 
amount of collision with stationary obstruction in a road accidents structure. It may indicate a better quality of the street surface and good traffic organisation. In this city are the lowest amount of accidents occurred due to drivers $-44.96 \%$ (an average of Ukraine is $78.85 \%$ ) and the standardised values of killed and injured people in the accidents for this reason (Figure 4).

If we talk about the outsiders of our regional ranking, after Khmel'nyts'ky region, Chernivtsi, Chernihiv, Kherson, Transcarpathian and Volyn' regions included into a group with the bad situation on the roads: the RSI value in 2007 not reached 10.0 (the average of Ukraine was 12.5). Analyzing the same data for 2013 , it can be seen that in most regions of Ukraine the level of the road safety has been improved. This was facilitated by changes in traffic rules, in particular the tightening of legislation, adapting to the requirements of the European Union (2008), increased penalties for violation of the rules: driving a car while drunk - from 32-52 to $350 €$, speeding - from 1.3-2.6 to $70 €$, non-use of seat belts - from 1.1 to $8.5 €$ (Road safety, 2012) as well as the repair or reconstruction of more than $2,000 \mathrm{~km}$ of main roads, made in preparation for the UEFA Euro 2012. However, the safety situation on the roads in some regions did not improve, yet deteriorated.

In 2013, the low value of RSI was recorded only in the Kherson region (Figure 5), mainly due to the undisciplined drivers. In this region there is the highest share of accidents with victims due to of drivers, the largest proportion of killed and injured in such accidents, etc.

As in 2007, Kyiv characterised by the safest roads: there was the lowest standardised value of road accidents with victims of the total number of all road accidents; the smallest proportion of rollover crashes among the traffic accidents with victims; the smallest amount of killed and injured people in road accidents due to child-pedestrians. Also in Kyiv are the smallest severity of accidents - only 0.07 persons killed per one accident with victims ( 0.15 in average for Ukraine), the lowest standardised value of accidents with victims occurred due to drivers, and the lower value of deaths and injuries in accidents of the same type.

The other leaders of this regional ranking in 2013 are the Transcarpathian region and Sevastopol'. In the Transcarpathian region is characterised by the smallest amount of car collisions among the accidents with victims, the lowest proportion of accidents with victims due to drunk drivers, the smallest standardised value of perished and injured people in accidents caused by drunk drivers. In addition, the smallest amount of accidents with victims occurred due to of pedestrians, including the fault of the children, was also recorded for the Transcarpathian region.

Bottom of our rankings, besides the Kherson region, consists of Khmel'nyts'kyi, Chernihiv, Volyn' and Vinnytsia regions where the RSI value in 2013 did not reach 11.5, while the average in Ukraine was 12.9. Moreover, the road safety in the Vinnytsia region during 2007-2013 is the most deteriorated as compared with other regions.

\section{Conclusions}

The analysis of the frequency of injuries and mortality in road accidents at the regional level in Ukraine allow us to define certain spatial features of the 


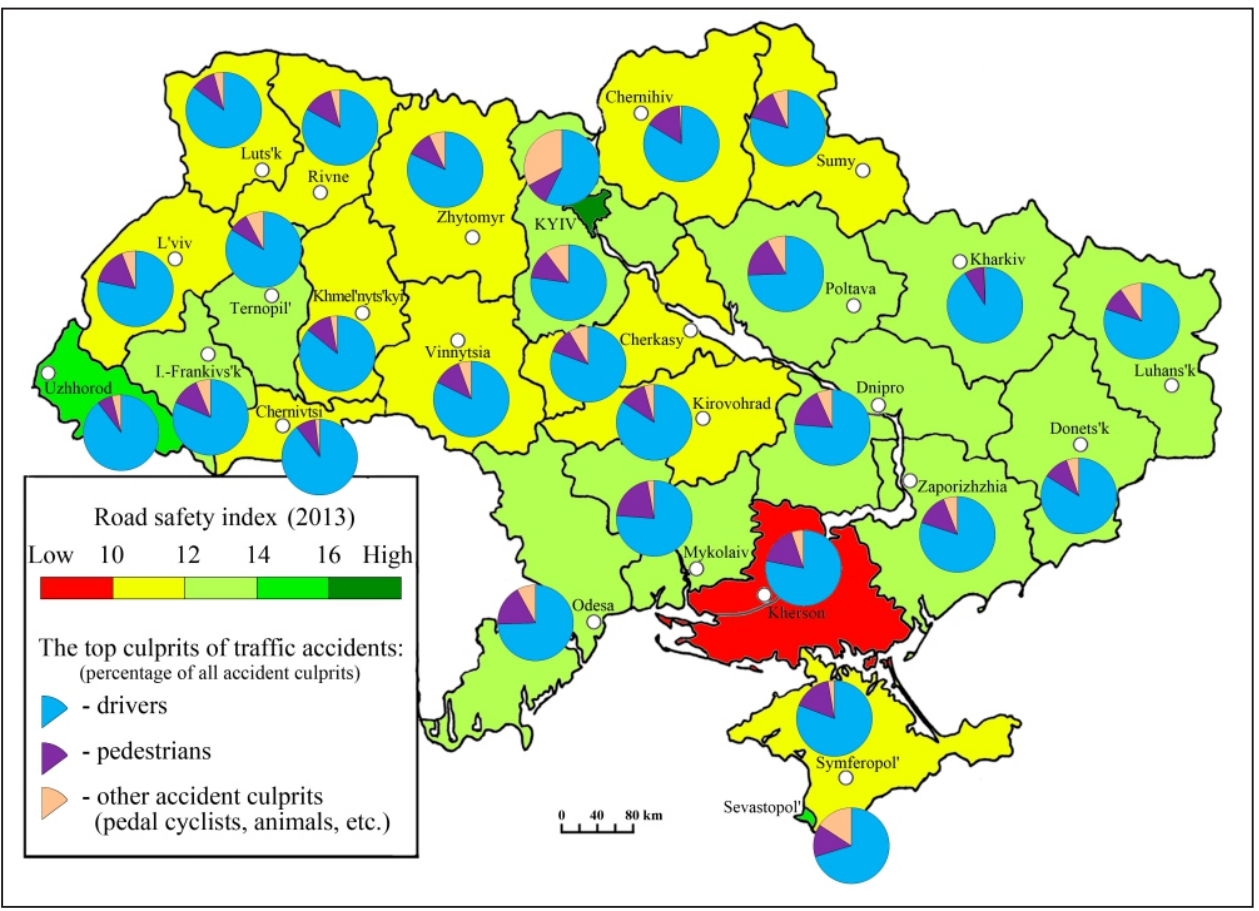

Figure 4. The road safety index in regions of Ukraine (2007)

Source: own edition.

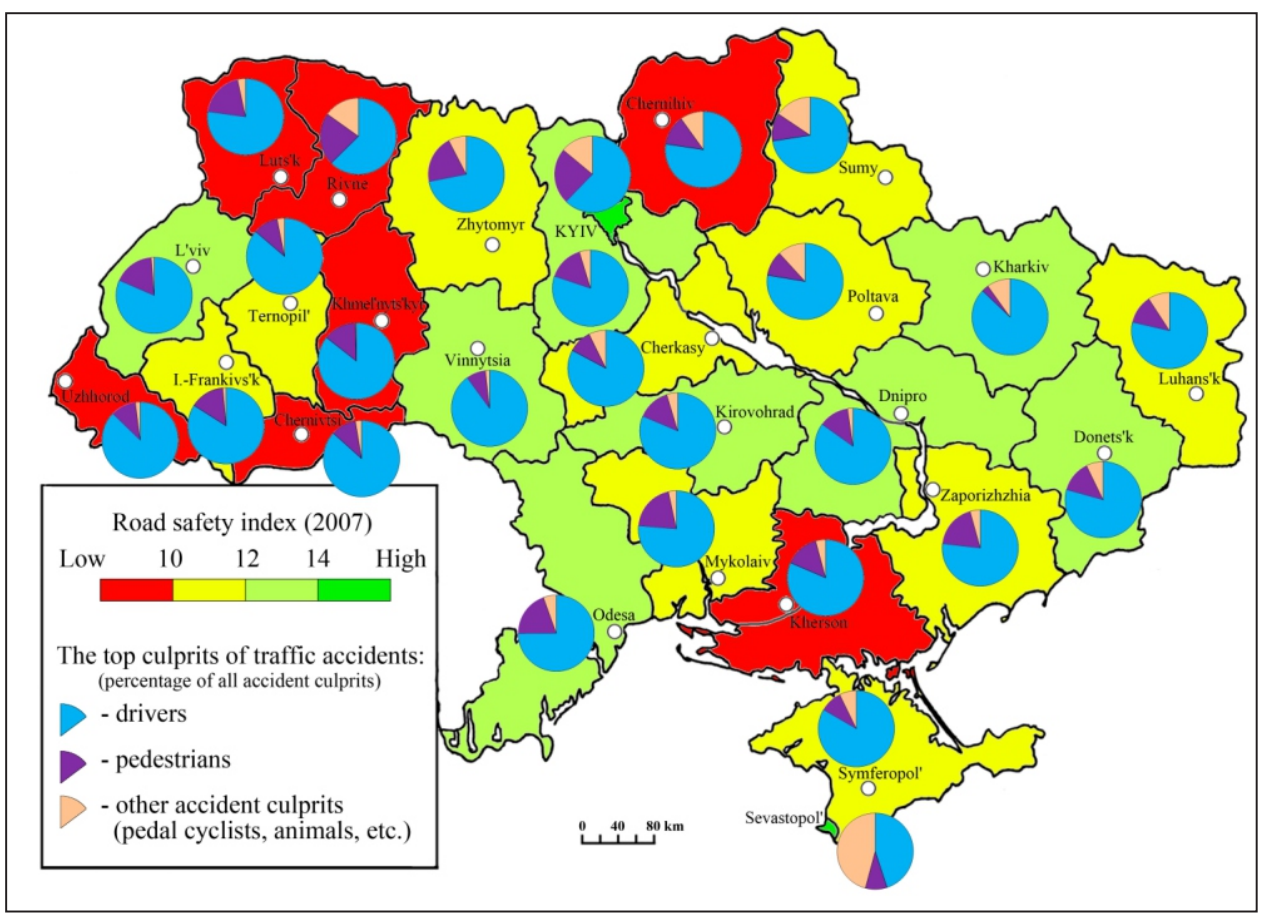

Figure 5. The road safety index in different regions of Ukraine (2013) Source: own edition. 
distribution of these indicators and on the non-random nature of the location of their values that is shown on maps of Ukraine. Based on the methods of statistic analyses, we have demonstrated the existence of a spatial structure in the distribution of the risks and consequences of traffic accidents in different regions of Ukraine.

In 2013, the road traffic death rate in Ukraine was about 10.7 per 100,000 population. This level was lower than in the Russian Federation (18.2), Belarus (13.7), and Republic of Moldova (12.5). However, the mortality rate in road accidents in Ukraine was much highest than in neighboring EU countries (Road traffic deaths, 2016): Bulgaria (8.3), Hungary (7.7), Romania (8.7), Slovakia (6.6 deaths per 100,000 population), and much worse than, for example, in Germany (4.3). As it can be seen, the death rate in road accidents in Ukraine is almost the same as in Lithuania (10.6) or Poland (10.3).

The value of RSI in 2007 is ranging from 8.5 in the Khmel'nyts'kyi region to 14,4-14,7 in Kyiv and Sevastopol' In 2013, the value of road safety index was ranged from 9.9 in the Kherson region to 16.7 in Kyiv. RSI enabled us to distinguish regions categorised by traumatism and mortality rates of road accidents. Based on analysis of these indicators we have introduced the evaluation of an integrated safety level for the different regions of Ukraine. This allows us to estimate the complex influence of the risks and their consequences (traffic accidents) on the level of safety for certain regions or their groups.

Most of the traffic accidents were due to driver factors. The percentage of accidents with victims occurred due to the fault of drivers in 2013 ranged from $57.28 \%$ in Kyiv to $91.19 \%$ in Kharkiv region. The main causes of accidents are speeding, unsuccessful manoeuvring, unsafe lane changes, violation of rules in the crossroads or marked crosswalks, driving a vehicle while intoxication through drink or drugs. Because of these violations in Ukraine committed about $55 \%$ of accidents. The statistics show that drivers, who commit traffic accidents, incorrectly assess their skills and ability to drive, can't anticipate dangerous situations and, consequently, can't properly deal with such cases. Many die as a consequence of inexperience or just plain recklessness.

The results of our research can be used for the improvement of national and regional programs of road and transport safety, as well as for the development of strategies and actions aimed at reducing the risks and consequences of traffic accidents in the regions of Ukraine. It is necessary to establish in more detail the reasons underlying the emergence of these factors at the local, regional or national levels and, by taking these reasons into account, to develop a complex of target actions to its reducing.

\section{References}

ACEA Communication Department 2015, The automobile industry pocket guide 2015-2016, ACEA, viewed 9 January 2017, https://goo.gl/FdEe6o.

Avramenko, VV \& Syutkin, SI 2015, 'Osoblyvosti dorozhn'o-transportnykh pryhod na avtoshlyakhakh Ukrayiny zalezhno vid rivnya sotsial'noekonomichnoho rozvytku rehioniv ta yikh turystychnoyi spryamovanosti' (Peculiarities of accidents on the Ukraine roads depending of the socio- 
economic development of regions and their tourist focus), Nauk. zap. Sums'kogo derž. pedagog. unìv. im. A.S. Makarenka, Geogr. nauki, no. 6, pp.158-169.

Beckmann, J 2007, (ed), Social and Economic Consequences of Road Traffic Injury in Europe, European Transport Safety Council, Brussels.

Borovkov, VN et al. 2011, 'Dorozhno-transportnyiy travmatizm kak kompleksnaya mediko-sotsialnaya problema poter zdorovya naseleniya Rossii' (Road traffic traumatism as complex medical-and-social problems of health's loss of the population of Russia), Traumatology and orthopedics of Russia, vol. 3, no. 61, pp.101-108.

Causes of death 2013, 'Standardised death rate per 100000 inhabitants annual data', Eurostat database, viewed 28 June 2016, https://goo.gl/SyhLo8.

Fink, D 2015, 'Dorozhno-transportnyie proisshestviya: prichinyi, preduprezhdenie, zaschita prav postradavshih' (Traffic accidents: reasons, prevention, protection of the victims), Law and State, vol. 2, no. 67, pp. 68-75.

Global Health Observatory 2015, World Health Organisation Data Repository, viewed 28 June 2016, https://goo.gl/hgXwSH.

Decade of Action for Road Safety 2011-2020 2011, Global Plan for the Decade of Action for Road Safety 2011-2020, World Health Organization, viewed 10 January 2017, https://goo.gl/3nB9gW.

Haddon, WJr. 1972, 'A Logical Framework for Categorizing Highway Safety Phenomena and Activity', Journal of Trauma, vol. 12, pp. 193-207.

Improving global road safety 2010, Resolution adopted by the General Assembly No 64/255, viewed 10 January 2017, https://goo.gl/BAo2yd.

International Statistical Classification of Diseases and Related Health Problems 2015, World Health Organization, viewed 10 January 2017, https://goo.gl/2Z38a7.

International Transport Forum 2014, Road Safety Annual Report, OECD/ITF, viewed 10 January 2017, https://goo.gl/SoZbC3.

Jackisch, J, Sethi, D, Mitis, F, Szymañski, T \& Arra, I 2015, European facts and the Global status report on road safety, World Health Organization, viewed 20 June 2016, https://goo.gl/f1TEZe.

Karmazina, O (ed) 2014, Transport and Communications of Ukraine, State Statistics Service of Ukraine, Kyiv.

Kornus O. et al 2015, Terytorial'no-nozolohichna struktura zakhvoryuvanosti naselennya Sums'koyi oblasti (Territorial-nosological structure of morbidity of the population in Sumy region), State Pedagogical University named after A.S. Makarenko, Sumy.

Koskovetskyi, V 2015, 'Road Safety in Ukraine. Cooperation with the European Union', The 10th Eastern Partnership Transport Panel, viewed 23 November 2016, https://goo.gl/pPnNUm.

Kovalchuk, AYu 2014, 'The characteristic of social-demographic situation and prevalence of the socially significant diseases in the Ukraine', Ukrainian Medical Journal, vol. 1, no. 99, pp. 29-33.

Kvitashvili, O 2015, (ed.), Shchorichna dopovid' pro stan zdorov"ya naselennya, sanitarno-epidemichnu sytuatsiyu ta rezul'taty diyal'nosti systemy okhorony zdorov"ya Ukrayiny (Annual report on the state of health, sanitary and epidemiological situation and the results of the health care system in Ukraine), Ministry of Health Care of Ukraine, Kyiv. 
Lyebyedyeva, TL 2015, 'Problemni pytannya bezpeky dorozhn'oho rukhu v Ukrayini (povidomlennya 1)' (Topical Issues Of Road-Traffic Safety In Ukraine (Report 1), Journal of Education, Health and Sport, vol. 5, no. 6, pp. 472-481.

Motorisation rate 2015, Eurostat database, viewed 28 June 2016, https://goo.gl/7QPCs6 .

Myronenko, SV \& Myronenko, KS 2013, 'Analiz vlijanija urovnja avarijnosti v ukraine na obshhuju tendenciju dorozhno-transportnoj situacii' (Analysis of impact of the accident rate in Ukraine on the general trend of road traffic situation), Information technologies in education, science and production, vol. 3, no. 4, pp. 59-65.

NA 2012, Road safety in Ukraine 2012, UNECE, viewed 28 June 2016, https://goo.gl/sNZQgD.

NA 2016, Road Statistics Yearbook 2016, European Union Road Federation, viewed 9 January 2017, https://goo.gl/GUPqrb.

NA 2014, 'Statystyka DTP u 2014 rotsi: de ta chomu?' (Accident statistics in 2014: where and why?), Information-analytical center Info-Light, viewed 10 January 2017, https://goo.gl/U5LzNZ.

NA 2016, Road traffic deaths. Data by country, WHO Global Health Observatory data repository, viewed 05 November 2016, https://goo.gl/vFTYmF.

Peden, M, Scurfield, R, Sleet, D, Mohan, D, Hyder, AA, Jarawan, E \& Mathers, C (eds.) 2004, World report on road traffic injury prevention, WHO, Geneva, viewed 10 January 2017, https://goo.gl/Lh7hr5.

Road fatalities in the EU since 2001 2016, European Commission, viewed 5 November 2016, https://goo.gl/ckE9xc.

Shyshchuk, V 2011, Aktual'ni problemy dorozhn'o-transportnoyi politravmy v umovakh ahrarno-industrial'noho rehionu (Actual problems of road traffic trauma in conditions of agro-industrial region), Publishing House Mriya, Sumy.

Shyshchuk, V et al. 2015, 'Dorozhniy travmatyzm ta rehional'na systema travmatolohichnoyi dopomohy: medychnyy ta terytorial'nyy aspekty (na prykladi Sums'koyi oblasti)' (Road traffic injuries and regional system of trauma care: medical and territorial aspects (case study of Sumy region), Journal of Education, Health and Sport, vol. 6, no. 9, pp. 460-470.

Statistics of road accidents in Ukraine 2016, Office of Road Safety of the Department of preventive activity of the National Police of Ukraine, viewed 5 November 2016, https://goo.gl/LPwepm.

UNECE 2015, Statistics of Road Traffic Accidents in Europe and North America, United Nations Economic Commission for Europe, vol. LIII, viewed 10 January 2017, https://goo.gl/aS8bFQ.

WHO Library Cataloguing-in-Publication Data 2009, Global status report on road safety: time for action, World Health Organization, viewed 10 January 2017, https://goo.gl/NC5JB7.

WHO Library Cataloguing-in-Publication Data 2013, Global status report on road safety 2013: supporting a decade of action, World Health Organization, viewed 10 January 2017, https://goo.gl/EzAZ5X.

WHO Library Cataloguing-in-Publication Data 2015, Global status report on road safety, World Health Organization, viewed 28 June 2016, https://goo.gl/F5caZq.

Zhuk, I (ed) 2015, Statistical Yearbook of Ukraine for 2014, State Statistics Service of Ukraine, Kyiv. 